\title{
PROTOTIPE DESAIN RUANG PRODUKTIF KELOMPOK IBU RUMAH TANGGA NELAYAN DI KAMPUNG UJUNG KASSI KELURAHAN BAROMBONG KOTA MAKASSAR
}

\author{
Andi Annisa Amalia ${ }^{*}$, Nurhikmah Paddiyatu², Andi Luhur Prianto ${ }^{3}$, Hamrun $^{4}$ \\ 1,2,3,4 Universitas Muhammadiyah Makassar \\ *annisa@unismuh.ac.id
}

\begin{abstract}
ABSTRAK
Masyarakat di Kampung Nelayan Ujung Kassi seringkali memanfaatkan bagian kolong rumahnya (siring) sebagai gudang, penyimpanan peralatan melaut, tempat istirahat, tempat jualan, tempat menidurkan anak serta aktivitas kelompok khususnya ibu rumah tangga nelayan. Karena beragamnya fungsi dan aktivitas yang dilakukan pada kolong rumah dengan luasan yang terbatas, maka dibuat prototype kolong rumah panggung yang dapat difungsikan sebagai ruang produktif bagi kelompok ibu rumah tangga nelayan. Metode yang digunakan adalah workshop dan Focus Group Discussion (FGD) dengan menggunakan pendekatan partisipatif desain. Hasil kegiatan Pengabdian ini adalah rancangan ruang produktif kolong rumah panggung, storage multifungsi, pelatihan membuat tanaman hias, dan aturan bersama dalam penggunaan ruang produktif nelayan. Rancangan ruang ini berimplikasi pada terbentuknya fungsi baru pada bagian bawah rumah panggung nelayan untuk melakukan aktivitas yang lebih bernilai produktif secara ekonomi dan berpotensi menunjang perekonomian rumah tangga nelayan. Selain itu, dengan adanya prototype tersebut eksistensi nilai sosial pada kolong rumah panggung nelayan sebagai sebagai ruang komunal tetap dipertahankan
\end{abstract}

Kata Kunci: Kampung Nelayan, Kolong Rumah Panggung, Ruang Produktif, Komunal

\begin{abstract}
Communities in Ujung Kassi Fishermen's Village often use the lower part of their house (under the house) as storage, storage for fishing equipment, resting places, selling places, sleeping places for kids, and group activities especially housewives of fishermen. Because of the variety of functions and activities carried out under the house with a limited area, then made a prototype under the stilt house that can function as a productive space for groups of fishermen housewives. The method used is a workshop and Focus Group Discussion (FGD) using a participatory design approach. The results of this Community Service activity are the design of productive spaces under stilts, multifunctional storage, training to make ornamental plants, and joint rules in the productive use of fishermen's spaces. This spatial design has implications for the formation of new functions at the bottom of the stage house of fishermen to carry out activities that are more economically productive and potentially support the fisheries household economy. In addition, with the existence of the prototype, the existence of social values under the fishing
\end{abstract} houses on stilts as a communal space is maintained

Keywords: Fisherman Village; Under Stage House; Productive Space; Communal

\section{PENDAHULUAN}

Kelurahan Barombong terletak di Kecamatan Tamalate dengan batas administratif di sebelah utara berbatasan dengan Tanjung Mardeka, sebelah timur berbatasan dengan Kanjilo Kabupaten
Gowa, sebelah selatan berbatasan dengan Desa Pakkatta Kabupaten Takalar dan sebelah barat berbatasan dengan Selat Makassar. Kelurahan Barombong yang terletak di pesisir utara Kota Makassar masih terdapat kampung nelayan yaitu 
Kampung Ujung Kassi. Secara administratif batas kampung nelayan ini di Sebelah Utara berbatasan dengan RW 02 Kelurahan Barombong, Sebelah Timur berbatasan dengan RW 01 Kelurahan Barombong, Sebelah Selatan adalah Kabupaten Takalar dan Sebelah Barat adalah Selat Makassar, dengan jarak tempuh menggunakan kendaraan bermotor ke Ibukota Makassar selama 15 menit.

Masyarakat di perkampungan nelayan Ujung Kassi Barombong adalah masyarakat yang hidup di Kawasan Pesisir, yaitu kawasan transisi antara darat dan Selat Makassar. Masyarakat nelayan rata-rata pada awalnya masih menggantungkan hidupnya pada laut. Namun Seiring dengan pesatnya pertumbuhan kawasan terutama adanya perluasan wilayah daratan dengan proyek reklamasi Pantai Losari, menjadikan nelayan harus melaut jauh diluar Pulau. Hal ini membuat beberapa kepala rumah tangga sudah mulai beralih profesi sebagai karyawan toko, buruh dan satpam pada perumahan dan fasilitas komersial yang ada di Tanjung Bunga.

Kondisi bangunan hunian pada permukiman Kampung Nelayan Ujung Kassi masih mempertahankan gaya vernakular Bugis Makassar dengan konstruksi rumah panggung. Salah satu ruang pada hunian yang paling sering digunakan kelompok nelayan untuk berkumpul, membuat jaring, beristirahat menyimpan peralatan melaut, dan menidurkan anak adalah bagian kolong rumah. Selain itu, untuk menunjang perekonomian keluarga, ibu rumah tangga nelayan juga membentuk kelompok yang aktif dalam pengembangan usaha pembuatan kripik rumput laut dan ikan asin. Aktivitas ekonomi ini juga dilakukan pada ruang kolong rumah untuk pengolahan hingga penjualan. Karena terbatasnya ruang bagi ibu rumah tangga nelayan untuk mengakomodir kebutuhannya dalam melakukan kegiatan kelompok mereka, maka diperlukan rancangan ruang khususnya pada kolong rumah panggung agar bisa dimanfaatkan seefisien mungkin untuk melakukan kegiatan produktif. Selain itu diperlukan upaya pengembangan livelihood nelayan dengan mengembangkan kelompok perempuan nelayan agar nantinya dapat menopang perekonomian rumah tangga.

Menurut Aminah

menyatakan bahwa kemiskinan di masyarakat nelayan tradisional yang ada di Indonesia karena pendapatan rendah, kurang keterampilan dan rendahnya standar hidup mengakibatkan istri nelayan ikut bekerja guna menopang penghasilan suami agar mampu bertahan hidup secara layak dan rata-rata mereka lebih memilih bekerja di publik produktif daripada berperan di domestik tradisional. Hal serupa juga dikatakan oleh Hikmah dkk (2009), peran dan konstribusi perempuan (istri) nelayan terhadap ekonomi keluarga tidak hanya dalam aktivitas domestik saja, tetapi istri juga terlibat dalam aktivitas produktif seperti penangkapan ikan di perairan umum yang dekat dengan lingkungan permukiman mereka, seperti rawa dan sungai. Selain itu, diperlukan upaya pengembangan kapasitas Ibu Rumah Tangga Nelayan untuk menciptakan peluang usaha baru untuk menopang perekonomian rumah tangga.

Beberapa program dari aspek eskternal yang umumnya sering dilakukan berupa penguatan kepada nelayan dalam bentuk pelatihan bagi ibu rumah tangga seperti membuat kerupuk, terasi dan olahan lainnya masih belum 
terasa memberikan dampak yang signifikan (Wigati dkk, 2015).

Perempuan pesisir perlu ditingkatkan kualitas dan kemandiriannya melalui kegiatan produktif diantaranya membentuk KUB untuk memudahkan akses informasi modal, pelatihan keterampilan aspek teknis dan variasi produk, melakukan penataan kelembagaan penyuluh, serta keberlanjutan dan diversivikasi usaha (Istiana, Hikmah dan Mursidin. 2008). Permasalahan lainnya bagi nelayan adalah fasilitas tempat penjemuran ikan belum tersedia, sehingga sebagian nelayan menjemur hasil tangkapannya di dermaga dan kolong-kolong rumah karena tidak terdapat wilayah khusus untuk memudahkan mereka mengelola dan memaksimalkan hasil tangkapannya (Nadjmi, 2019).

Kelompok Ibu Rumah Tangga Nelayan Barombong terdiri dari kelompok istri-istri dari nelayan yang ada di Kampung Ujung Kassi Kelurahan Barombong Kota Makassar. Mereka tergabung dalam Kelompok Mawar yang diketuai oleh ibu $\mathrm{RT} \quad 05$ RW 04 Bontokapetta. Kelompok ini terbentuk sejak tahun 2005 atas dasar adanya kesamaan aktivitas dan orientasi kaum perempuan nelayan untuk mengembangkan kapasitasnya yang kedepannya mereka berharap dapat menunjang perekonomian keluarga nelayan. Sejak terbentuknya Kelompok Mawar hingga saat ini jumlah anggota terdiri dari 10 orang yang berasal dari ibu rumah tangga nelayan. Pada tahun 2014, Kelompok Mawar mendapat bantuan stimulan pengembangan usaha rumah tangga kelompok untuk pembelian peralatan usaha. Selain itu, mereka juga mendapatkan beberapa pelatihan pengembangan kapasitas berupa pelatihan kemasan produk kripik rumput laut.

Beberapa kegiatan kelompok yang aktif dilakukan hingga saat ini adalah pelatihan dan penyuluhan kesehatan ibu dan anak anak balita nelayan, pelatihan pemasaran produk, pelatihan pengelolaan Kawasan, praktek partisipatif penyusunan rencana penataan lingkungan permukiman kumuh, serta exercise penyusunan peta tematik kampung nelayan. Adapun kendala Kelompok Mawar selaku mitra kegiatan pengabdian adalah tidak adanya ruang khusus untuk melakukan aktivitas bersama dalam pengembangan kapasitas kelompok, tidak adanya tempat penyimpanan hasil olahan perikanan yang diproduksi oleh kelompok seperti rumput laut maupun ikan asin serta minimnya keterampilan Ibu Rumah Tangga Nelayan dalam menata potensi alam perikanan dan belum adanya kreativitas pengembangan livelihood kelompok khususnya yang dapat menungjang ekonomi rumah tangga.

\section{METODE}

Metode yang akan digunakan dalam kegiatan Program Pengembangan Masyarakat (PPM) ini adalah workshop dan Focus Group Discussion (FGD) dengan menggunakan pendekatan partisipatif desain. Dalam proses pembangunan, ada enam metode yang dapat digunakan untuk memberikan ruang partisipasi masyarakat yaitu pemetaan sosial, FGD penyusunan desain awal, diskusi dan konsultasi desain final, perlibatan masyarakat dalam pembanguna fisik, penyusunan rencana kegiatan dan kendala di lapangan dan mitigasinya (Permanasari, et.al., 2018).

Tempat dan Waktu. Tempat pelaksanaan kegiatan PPM adalah di Kampung Ujung Kassi Kelurahan Barombong Kota 
Makassar. Waktu Pelaksanaan pada 2019. Adapun peta lokasi kegiatan dapat Bulan Agustus hingga Oktober Tahun dilihat pada gambar 1 berikut.

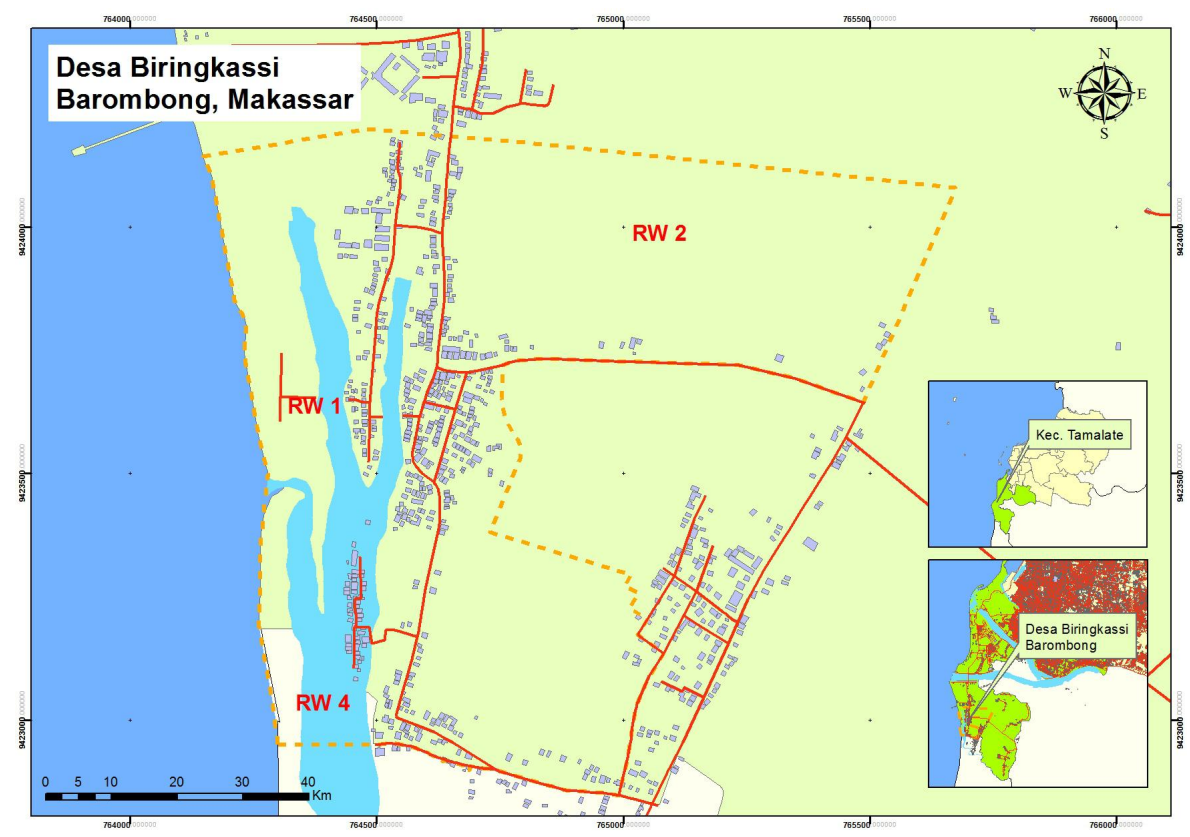

Gambar 1. Peta Lokasi Kegiatan PPM Kampung Nelayan Ujung Kassi/Biringkassi

Khalayak Sasaran. Khalayak sasaran selaku mitra kegiatan adalah Kelompok Perempuan Nelayan yang tergabung dalam Kelompok Mawar terdiri dari ibu rumah tangga nelayan yang ada di Kampung Ujung Kassi Barombong berjumlah 15 orang.

Metode Pengabdian. Adapun metode pelaksanaan kegiatan terdiri atas beberapa tahapan sebagai berikut :

1. Sosialisasi dan FGD penyusunan konsep ruang produktif dilakukan secara partisipatif. Melalui FGD ini, dipaparkan rancangan prototipe desain kepada masyarakat.Prototype desain dilakukan dengan studi model dan studi terhadap bentuk dengan mengadopsi bentuk tertentu sebagai inspirasi agar furniture lebih menarik bagi pemakai (Oentoro dan Elsafany, 2016).

2. Ekspose Desain dilakukan dihadapan masyarakat dengan menampilkan visualisasi model ruang produktif dan furnitur modifikatif. Furnitur modifikatif adalah furni

3. Pembuatan Storage multifungsi dilakukan dengan tahapan pengukuran, pengenalan bahan dan alat, teknis pembuatan furniture modifikatif, perakitan furnitur yang dilakukan bersama masyarakat.

4. Pelatihan membuat tanaman hias dengan menggunakan metode kokedama

5. Penyusunan aturan bersama dilakukan oleh kelompok ibu rumah tangga nelayan dengan membuat aturan bersama yang disepakati terutama dalam hal penggunaan ruang produktif dan storage modifikatif serta mekanisme pemeliharaan anggota kelompok.

Indikator Keberhasilan. Adapun indikator keberhasilan kegiatan ini adalah (1) Terbentuknya pemahaman kepada masyarakat dalam pemetaan perilaku dan layout ruang yang nyaman dan sesuai 
fungsi sebagai dasar dalam rancangan model prototype ruang produktif yang menjadi stimulan dalam pengembangan industri rumah tangga nelayan, Terwujudnya ruang produktif yang layak dan dapat digunakan secara komunal oleh ibu rumah tangga nelayan,

Meningkatnya keterampilan Ibu Rumah Tangga Nelayan untuk berkreasi menciptakan usaha baru melalui peningkatan kapasitas Teknik membuat tanaman hias dengan metode kokedama, (4) Adanya prototype desain dalam pemanfaatan kolong rumah panggun nelayan sebagai ruang produktif yang dibuat secara partisipatif.

Metode Evaluasi. Metode evaluasi yang dilakukan untuk mengukur keberhasilan kegiatan PPM melalui evaluasi proses, evaluasi akhir dan evaluasi tindak lanjut. Evaluasi proses dilihat pada saat simulasi pembuatan storage serta simulasi pembuatan layout ruang produktif, dan praktek pembuatan kokedama. Evaluasi akhir dilakukan dengan praktek mandiri tim kelompok perempuan nelayan membuat tanaman hias kokedama jumbo, penyepakatan aturan bersama penggunaan dan pemeliharaan ruang produktif, serta keberfungsian storage yang telah dibuat bagi kelompok perempuan nelayan. Evaluasi tindak lanjut dilakukan dengan melihat aturan bersama yang telah diterapkan dan papan bicara aturan bersama telah terpasang pada rumah yang dijadikan tempat berkumpul kelompok ibu rumah tangga nelayan.

\section{HASIL DAN PEMBAHASAN}

Pelaksanaan kegiatan PPM Prototipe Ruang Produktif Nelayan Kampung Ujung Kassi telah dilakukan kegiatan Sosialisasi dan FGD (Focus Group Discussion) penyusunan desain ruang produktif, ekspose desain dan pembuatan storage multifungsi, Pelatihan membuat tanaman hias kokedama, serta penyusunan aturan bersama penggunaan dan pemeliharaan ruang produktif, storage dan tanaman hias.

\section{A. Sosialisasi dan FGD Penyusunan Desain Ruang Produktif}

Tahap sosialisasi kegiatan Program Kemitraan Masyarakat adalah memperkenalkan tahapan kegiatan PKM, pemaparan kelompok mitra mengenai profil kelompok. Inti dari sosialisasi ini adalah kesepahaman dan partisipasi masyarakat kampung nelayan Ujung Kassi khususnya Kelompok Mawar untuk ikut serta dalam seluruh rangkaian kegiatan PKM. Selain itu pada kegiatan ini juga Kelompok Mawar menjelaskan kepada pihak mitra bentuk bentuk kegiatan yang sudah dilakukan oleh kelompok mawar seperti pelatihan pembuatan dan pengemasan kripik rumput laut, pelatihan pemasaran dari Dinas Perikanan dan Kelautan Kota Makassar. Mereka juga baru-baru ini telah dibekali kegiatan peningkatan kapasitas dengan metode penataan lingkungan permukiman dan metode desain partisipatif dari UIN Alauddin Makassar di tahun 2018 berupa desain signage sebagai identitas kampung nelayan dan penataan fasade bangunan hunian. Kemudian di Tahun 2019 dilanjutkan dengan penataan elemen ruang komunal. Dari kegiatan tersebut dapat disimpulkan bahwa metode desain partisipatif bukanlah hal baru bagi Kelompok Mawar karena sudah pernah diaplikasikan sebelumnya khususnya dalam pengembangan lingkungan permukiman mereka.

Setelah tahap sosialisasi, maka dilanjutkan dengan penyusunan konsep ruang produktif, dimana proses ini lebih banyak menggali ide dari masyarakat yang dilakukan dengan metode FGD agar lebih terarah. Dalam FGD ini, Tim Pengabdi dari Arsitektur menyampaikan usulan desain gambar 2 berupa ruang produktif di bagian kolong rumah 


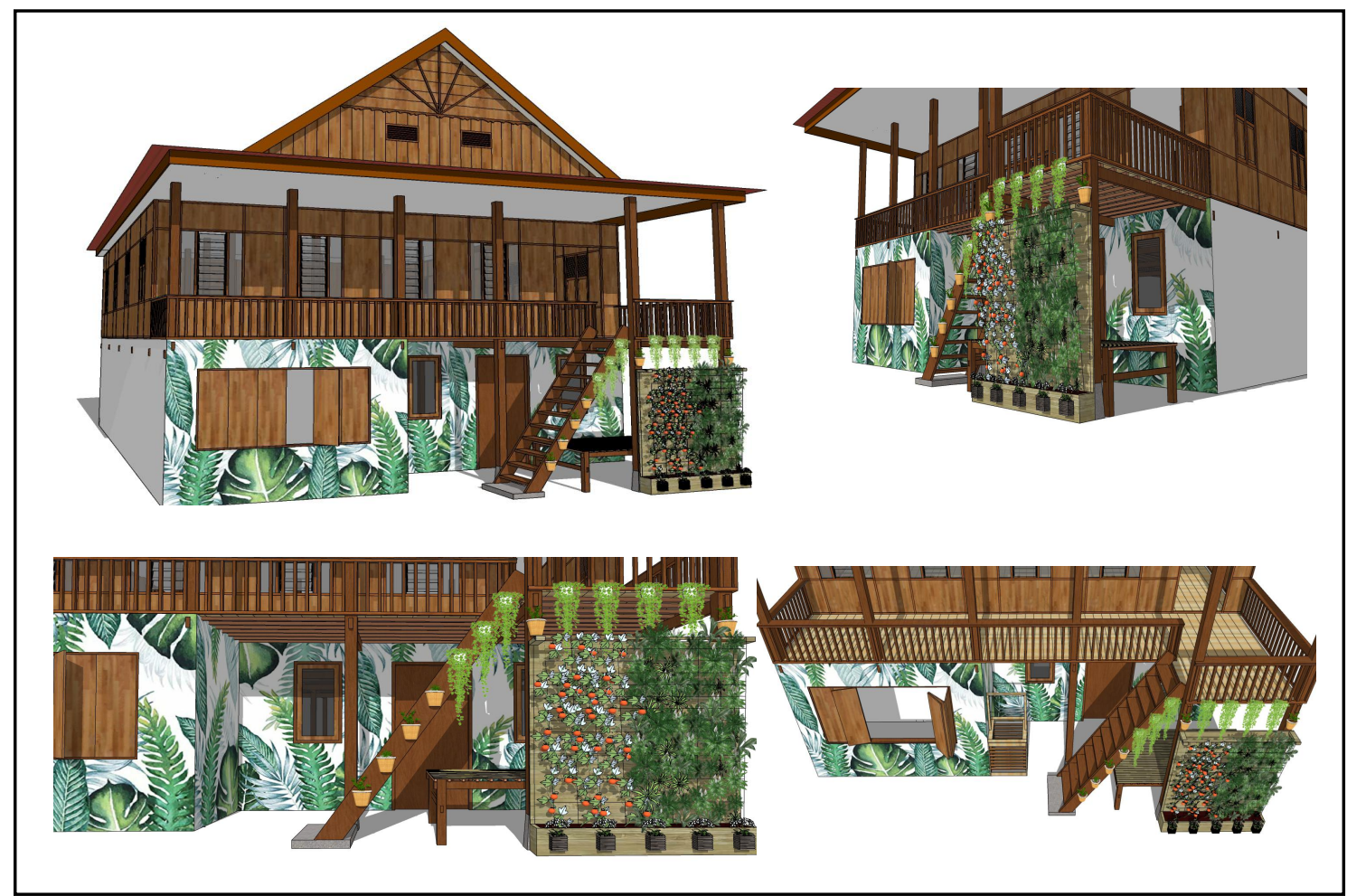

Gambar 2. Prototipe Desain Ruang Produktif pada Rumah Nelayan

Pada FGD ini, Tim Arsitek menjelaskan tentang prototipe rancangan yang diusulkan sesuai dengan luasan ruang yang tersedia pada Kolong Rumah Panggung Nelayan. Sampel model ruang yang diambil adalah Kolong Rumah Panggung Milik Ketua RT 4 RW 5 Kampung Ujung Kassi. FGD ini dihadiri oleh ibu-ibu rumah tangga nelayan yang berjumlah sekitar 20 orang. Desain bangunan menghasilkan ruangan yang sifatnya terbuka dan dapat digunakan multifungsi tanpa menghilangkan fungsi ruang sebelumnya. Hasil identifikasi dari FGD bahwa ibu-ibu nelayan setuju untuk tetap memfungsikan ruang bawah (disebut siring dalam Bahasa Makassar) sebagai ruang usaha dan ruang komunal. Sehingga layout ruang terdiri dari kios, bale-bale, penempatan storage (penjemuran ikan asin dan kripik), etalase tanaman hias dan sirkulasi dari area dapur dan penempatan tangga dari bagian atas kolong (badan rumah). Gambar desain ini dipresentasikan dan didiskusikan dengan pihak mitra untuk mendapatkan umpan balik sehingga dapat menampung kebutuhan mereka.

\section{B. Ekspose Desain Ruang Produktif dan Pembuatan Storage Multifungsi}

Tahapan selanjutnya adalah mendesain storage multifungsi. Desain ruang produktif yang telah dilengkapi dengan elemen storage kemudian diekspose kembali dihadapan masyarakat yang hasilnya masyarakat pada dasarnya menyetujui desain ruang produktif namun masih ada beberapa masukan untuk penyempurnaan desain kedepannya diantaranya desain ruang produktif tidak terbatas di satu unit hunian saja sebagai sampel tetapi keseluruhan rumah nelayan karena ada beberapa tipe hunian, desain menyesuaikan dengan kebutuhan dan keinginan penghuni, desain ruang komunal pada ruang terbuka yang lebih luas. Rekomendasi dari ekspose tersebut sebagai masukan, tetapi memang untuk 
ditindaklanjuti saat ini masih terdapat beberapa kendala terutama untuk membuat rancangan ruang komunal di ruang terbuka harus mendapat persetujuan dari pihak pemerintah kelurahan karena terkait ijin pemanfaatan lahan. Selain itu untuk prototipe desain yang tidak dibuat keseluruhan karena mengingat sampel satu unit bangunan hunian sudah mengespresikan beberapa unit bangunan yang ada untuk menjadi stimulan dalam menata layout ruang produktif di rumah mereka masingmasing karena rata-rata aktivitas pada kolong rumah hampir sama.

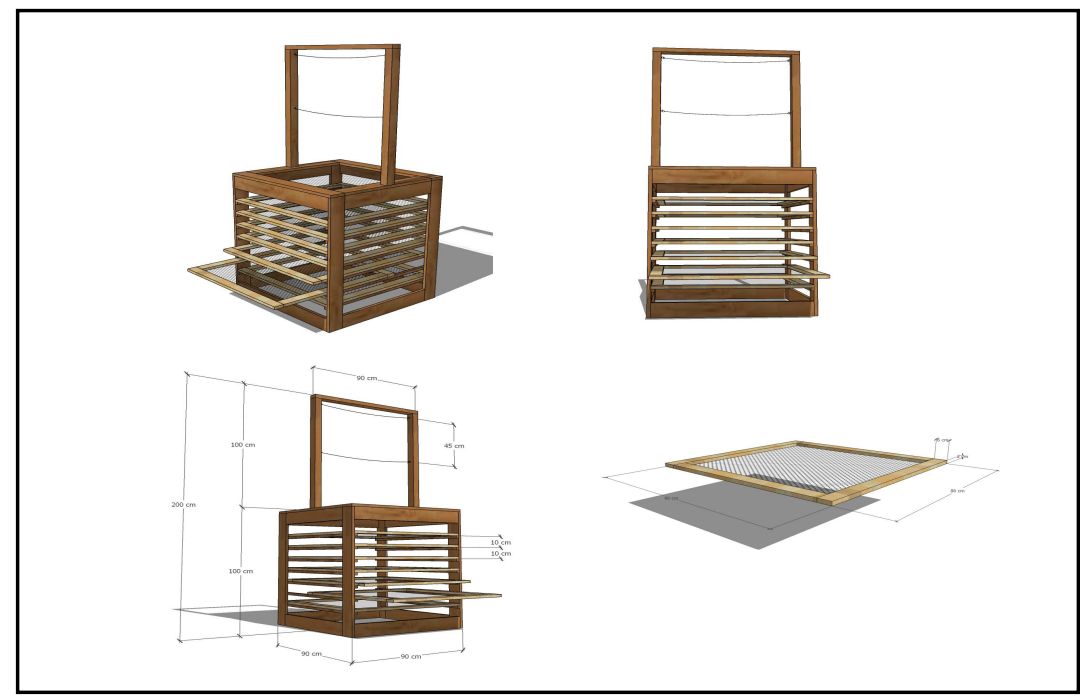

Gambar 3. Rancangan Storage Multifungsi

Setelah ekspose desain final, maka dilanjutkan dengan pembuatan storage multifungsi. Kegiatan ini melibatkan beberapa nelayan, buruh dan didampingi oleh 3 orang mahasiswa arsitektur. Pelaksanaan kegiatan diawali dengan pembuatan rangka kayu sebagai rangka, pembentukan rangka, dan pengecatan. Setelah rangka utama selesai, maka untuk memudahkan agar storage mudah dipindahkan maka dipasang roda pada empat sisi storage. Setelah itu dilakukan simulasi penggunaannya kepada ibu-ibu rumah tangga nelayan. Keunggulan storage ini, selain fungsi utama sebagai tempat penyimpanan krupuk, dapat juga digunakan untuk penjemuran ikan asin, penjemuran kripik, dan dapat pula digunakan sebagai etalase jualan yang mudah dipindahkan.

\section{Pelatihan Pembuatan Tanaman Hias Kokedama}

Pelatihan pembuatan tanaman hias dilakukan pada bale-bale yang berada di kolong rumah nelayan. Narasumber pelatihan adalah Tim Entrepreneurship Komunitas Kokedama Universitas Fajar Makassar yang terdiri dari empat orang. Peserta kegiatan ini adalah kelompok Ibu Rumah Tangga Nelayan. Peserta sangat antusias mengikuti karena mereka belum pernah melakukan kegiatan pengembangan kapasitas seperti ini sebelumnya, sehingga metode merangkai tanaman hias kokedama dengan media lumut dan pasir adalah hal yang sangat baru.

Tahapan kegiatan pelatihan diawali dengan pengenalan alat dan bahan yang digunakan diantaranya tali tambang yang agak kecil, media lumut diganti dengan sekam bakar, tanaman pilihan merupakan swadaya masyarakat dari tanaman yang ada di sekitar rumah mereka, campuran pupuk, pasir dan tanah, gunting, spray botol dan air serta baskom. Kemudian untuk memudahkan kegiatan, maka peserta pelatihan masing masing berpasangan membuat satu tanaman kokedama. Adapun cara membuatnya 
adalah (1) Ambil tanaman yang akan digunakan, lalu sisihkan tanah yang masih menempel pada akarnya, (2) Setelah bersih, akar dibungkus tanman dengan gumpalan sekam bakar hingga tertutupi semuanya, tekan sedikit-sedikit agar semuanya Bersatu, (3) Kemudian campur pupuk, tanah, pasir, sedikit sekam bakar dan juga menambahkan air sedikit dan mulai membuat dan membentuk campuran tersebut seperti bola-bola, bentuk disesuaikan, (4) Setelah bola-bola tanah selesai dibentuk, masukkan tanaman tadi yang sudah dibungkus dengan sekam bakar ke dalam bola bola tanah tadi, (5) Selanjutnya bila tanaman sudah menyatu pada bola-bola tanah dengan sekam bakar, kemudian ikat dengan menggunakan tali tambang agar bola tanah dan sekam bakar menyatu dengan baik.

Setelah tanaman kokedama selesai dibentuk, masing-masing kelompok testimoni proses dan tantangan selama membuat kreasi tanaman hias dengan Teknik kokedama. Kemudian Narasumber mengevaluasi hasil karya peserta. Hasil tanaman hias yang dibuat peserta masih ada yang belum terbentuk utuh bola-bolanya, tanaman masih ada yang ukurannya tidak proporsional dengan besar bola yang terbentuk, terdapat juga kelompok yang bolanya mudah hancur, dan rata-rata teknik mengikat bola-bola tanaman belum terlihat rapih. Dari keempat kelompok pelatihan, terdapat satu kelompok yang hasil merangkai tanamannya sudah cukup bagus sehingga oleh narasumber disarankan untuk mencoba membuat kokedama secara mandiri dengan ukuran yang lebih besar dan melatih perempuan nelayan yang tidak mengikuti kegiatan pelatihan ini.

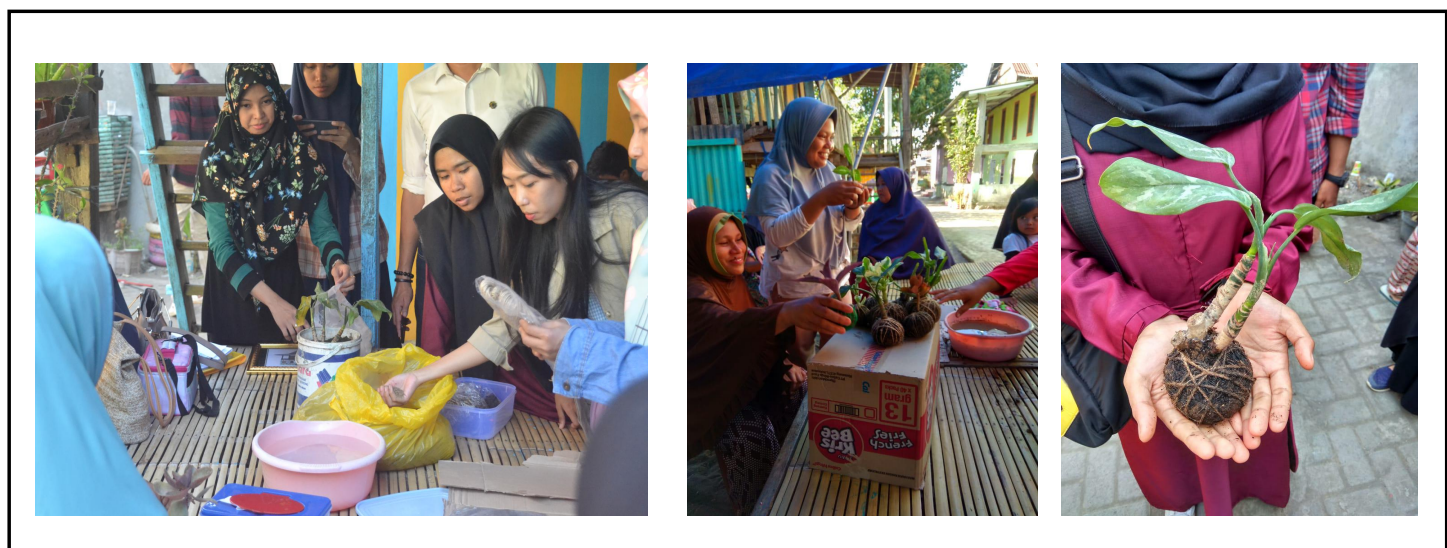

Gambar 4. Pelatihan Pembuatan Tanaman Hias Kokedama

\section{Penyusunan Aturan Bersama}

Aturan bersama merupakan hasil kesepakatan masyarakat nelayan Kampung Ujung Kassi diantaranya adalah kesepakatan tentang aturan pemanfaatan dan pemeliharaan ruang produktif, penataan tampilan bangunan, kesepakatan penggunaan storage, dan kesepakatan sisi kelembagaan kelompok perempuan nelayan. Hasil kesepakatan ini bersumber dari hasil rembug bersama nelayan, ibu rumah tangga nelayan, Ketua RT dan Ketua RW 5. Adapun aturan bersama yang telah dibuat dapat dilihat pada tabel berikut. 
Tabel 1. Arahan Aturan Bersama Ruang Produktif Nelayan

\begin{tabular}{|c|c|c|c|}
\hline Aspek & Kondisi Eksisting & Arahan Desain & $\begin{array}{l}\text { Aturan Bersama yang } \\
\text { disepakati }\end{array}$ \\
\hline $\begin{array}{l}\text { Pemanfaatan } \\
\text { Kolong } \\
\text { Rumah } \\
\text { Nelayan }\end{array}$ & $\begin{array}{l}\text { Pemanfaatan } \\
\text { sebagai ruang } \\
\text { usaha, peralatan } \\
\text { melaut, istirahat }\end{array}$ & $\begin{array}{l}\text { Bagian bawah } \\
\text { rumah dapat } \\
\text { digunakan untuk } \\
\text { kegiatan produktif, } \\
\text { etalase tanaman } \\
\text { hias dalam bentuk } \\
\text { vertikal }\end{array}$ & $\begin{array}{l}\text { Pemanfaatan kolong } \\
\text { rumah (siring) sebagai } \\
\text { kios usaha, bale-bale } \\
\text { (tempat istirahat), } \\
\text { ruang berkumpul, } \\
\text { tempat pengeringan } \\
\text { ikan asin dan kripik } \\
\text { dan etalase tanaman } \\
\text { hias }\end{array}$ \\
\hline $\begin{array}{l}\text { Pemeliharaan } \\
\text { ruang } \\
\text { produktif } \\
\text { nelayan }\end{array}$ & $\begin{array}{l}\text { Kondisi } \\
\text { permukaan lantai } \\
\text { masih ada berupa } \\
\text { tanah, penempatan } \\
\text { peralatan nelayan } \\
\text { tidak beraturan dan } \\
\text { menjadi tempat } \\
\text { sampah dan } \\
\text { penumpukan } \\
\text { barang yang sudah } \\
\text { tidak terpakai }\end{array}$ & $\begin{array}{l}\text { Pengecatan } \\
\text { dinding, perbaikan } \\
\text { permukaan lantai } \\
\text { dengan keramik } \\
\text { atau floor, penataan } \\
\text { layout ruang }\end{array}$ & $\begin{array}{l}\text { Penataan layout ruang, } \\
\text { pengecatan dinding } \\
\text { dan perbaikan } \\
\text { permukaan lantai, } \\
\text { membersihkan secara } \\
\text { rutin setiap hari }\end{array}$ \\
\hline $\begin{array}{l}\text { Penataan } \\
\text { Tampilan } \\
\text { bangunan } \\
\text { hunian }\end{array}$ & $\begin{array}{l}\text { Berbentuk rumah } \\
\text { panggung Bugis } \\
\text { Makassar, kolong } \\
\text { rumah tidak tertata } \\
\text { dengan baik, tidak } \\
\text { adanya unsur alami } \\
\text { seperti tanaman }\end{array}$ & $\begin{array}{l}\text { Fasade didesain } \\
\text { sesuai bentuk asli } \\
\text { dengan } \\
\text { penambahan } \\
\text { elemen tanaman } \\
\text { hias (softscape) } \\
\text { pada tangga dan } \\
\text { kolong rumah, } \\
\text { mural tema tropis } \\
\text { pada dinding } \\
\text { kolong rumah }\end{array}$ & $\begin{array}{l}\text { Bentuk asli tetap } \\
\text { dipertahankan, } \\
\text { penambahan elemen } \\
\text { hijau pada tangga dan } \\
\text { pembatas bangunan } \\
\text { dengan jalan sekaligus } \\
\text { sebagai dinding } \\
\text { transparan berupa } \\
\text { etalase tanaman hias } \\
\text { dalam bentuk vertical } \\
\text { garden }\end{array}$ \\
\hline $\begin{array}{l}\text { Penggunaan } \\
\text { storage }\end{array}$ & $\begin{array}{l}\text { Olahan hasil laut } \\
\text { seperti kripik } \\
\text { rumput laut dan } \\
\text { ikan asin hanya } \\
\text { dijemur di bale- } \\
\text { bale atau ruang } \\
\text { kosong di sekitar } \\
\text { rumah }\end{array}$ & $\begin{array}{l}\text { Storage didesain } \\
\text { multifungsi sesuai } \\
\text { kebutuhan } \\
\text { kelompok }\end{array}$ & $\begin{array}{l}\text { Storage akan } \\
\text { digunakan sebagai } \\
\text { tempat penjemuran } \\
\text { ikan dan kripik rumput } \\
\text { laut }\end{array}$ \\
\hline $\begin{array}{l}\text { Kelembagaan } \\
\text { Kelompok } \\
\text { Perempuan } \\
\text { Nelayan }\end{array}$ & $\begin{array}{l}\text { Terdapat } 1 \\
\text { kelompok nelayan } \\
\text { yaitu Kelompok } \\
\text { Mawar }\end{array}$ & $\begin{array}{l}\text { Adanya rencana } \\
\text { kerja kelompok, } \\
\text { sekretariat } \\
\text { kelompok, } \\
\text { identifikasi pihak } \\
\text { mitra kelompok }\end{array}$ & $\begin{array}{l}\text { Pembuatan rencana } \\
\text { kerja, identifikasi } \\
\text { pihak mitra, dan } \\
\text { Rumah Ketua RT } \\
\text { dijadikan tempat } \\
\text { berkumpul Kelompok }\end{array}$ \\
\hline
\end{tabular}

Sumber: Hasil Kesepakatan Masyarakat Nelayan (2019) 


\section{E. Keberhasilan Kegiatan Rancangan Ruang Produktif Nelayan}

Keberhasilan kegiatan PKM Prototipe desain ruang produktif bagi ibu rumah tangga nelayan adalah pengembangan kapasitas kelompok perempuan nelayan dalam berkreasi dalam mengembangkan ekonomi rumah tangga, pola perancangan ruang produktif nelayan yang melibatkan masyarakat, tertatanya rumah nelayan dan fungsi kolong rumah lebih produktif tanpa menghilangkan nilai local dan fungsi komunal, dan terbentuknya aturan bersama dalam pengelolaan ruang produktif.

\section{SIMPULAN}

Prototipe Ruang Produktif Nelayan dirancang secara partisipatif yang berbasis kearifan lokal, potensi fisik dan non fisik, serta kebutuhan masyarakat. Keberadaan ruang produktif nelayan merupakan salah satu bentuk pengembangan livelihood kampung nelayan yang tetap berkarakter dan menunjang keberlanjutan dan eksistensinya sebagai kampung nelayan. Diharapkan selanjutnya dengan adanya aturan bersama dan penguatan kapasitas, Kelompok Perempuan Nelayan dapat bermitra dengan pihak luar dalam menata kampung nelayan Kampung Ujung Kassi.

\section{DAFTAR PUSTAKA}

Aminah, F. 2011. Makna Wanita Tentang Perubahan Peran (Hasil Kajian Disertasi Wanita Istri Nelayan Suku Kaili dalam Perubahan Peran dari Domestik Tradisional ke Publik Produktif. Media Litbang Sulsel, IV, 12-23.
Hikmah, Yulisti, M., Nasution, Z. 2009. Pola Pembagian Kerja dan Kontribusi Gender terhadap Pendapatan Keluarga: Studi Kasus Rumah Tangga Nelayan di Desa Batanjung Kabupaten Kapuas. Bijak dan Riset Sosek KP, 4, 93-103.

Istiana, Hikmah, Mursidin. 2008. Optimalisasi Peran Gender dalam Upaya Peningkatan Kesejahteraan Nelayan. Bijak dan Riset Sosek KP, 3, 199-212.

Nadjmi, N. 2019. Kearifan Lokal, Fasilitas Ruang Terbuka Hijau dan Fasilitas Nelayan di Desa Nelayan Pantai Bahari. TALENTA Conference Series 01, 16-28.

Oentoro, K., Elsafany, B. 2016. Pengembangan Desain Furnitur Anak Berbahan Kertas Semen Bekas dengan Teknik Laminasi dan Spiral Wound Tubing. Jurnal IDEALOG, Jurnal Desain Interior dan Desain Produk, 1, 97-112.

Permanasari, E., Nugraha, H., Nurhidayah, F. 2018. Metode Partisipatif sebagai Model Pembangunan 6RTPTRA DKI Jakarta. Universitas Pembangunan Jaya Jakarta.

Wigati, S., Fauziyah, N., Afandi, A. 2015. Saving Group Perempuan Nelayan: Penguatan Ekonomi Nelayan Tradisional Berbasis Komunitas Pengajian Perempuan Desa Kaliuntu Kecamatan Jenu Kabupaten Tuban. Kementrian Agama Republik Indonesia, Direktorat Pendidikan Islam Ditjen Pendidikan Tinggi Islam. 